\title{
Service Quality Assessment of Online Shops on Facebook Fan Pages in Thailand
}

\author{
Pirapon Supakkeittikul and Yachai Limpiyakorn ${ }^{+}$ \\ Department of Computer Engineering, Chulalongkorn University, Bangkok 10330, Thailand
}

\begin{abstract}
Nowadays, Facebook is considered one of the most popular social network sites. In Thailand, open a shop via Facebook is very popular. Many shops have been opened via Facebook fan pages but the customers hardly know how trustworthy these online shops are. This paper thus presents an approach for assessing the service quality of SME online shops on Facebook fan pages. A Facebook fan page in Thailand with around 1.4 million likes was selected to demonstrate the proposed method. The quality dimensions and the assessment subjects are derived from the SERVQUAL model. The results of assessment provide 5-star overall rating and the detailed rating of each subject evaluation that would help the customers make decisions on their online shopping.
\end{abstract}

Keywords: service quality assessment, online shop, Facebook fan page.

\section{Introduction}

The growth of Social Networks plays an important role as one of marketing channels in modern electronic commerce, or E-commerce. Many online shopping web sites have been developed to serve the new era of online shopping lifestyle. Formerly, online shops were opened via the well-known E-commerce sites, such as eBay, or their own created web sites. The advent of Facebook and its popularity adequately provide a means of doing E-commerce businesses. In particular, small businesses can use Facebook fan pages as their online shops for retail sales direct to consumers. Without any cost of web site development or advertisement, Facebook fan pages are not intentionally designed for online stores, though. They lack some features that affect service quality, such as customer's feedback, order management system, stock management system, and customer care system. Moreover, unlike eBay, Facebook fan pages do not have service quality rating. The customers have to read the fan page's timeline for feedbacks from other customers. This paper thus presents an approach for assessing service quality on Facebook fan page shops. The information of the fan page, such as posts, likes, and comments, is collected for computing the service quality rating of an individual online shop.

\section{Related Work}

Parasuraman et al. [1] proposed a service quality model for service quality assessment in 1985 . The authors introduced 10 dimensions of service quality: Reliability, Responsiveness, Competence, Access, Courtesy, Communication, Creditability, Security, Understanding/Knowing the customer, and Tangible. Later in 1988, Parasuraman et al. [2] combined and regrouped the 10 service quality dimensions into 5 dimensions: Tangible, Reliability, Responsiveness, Assurance, and Empathy. The authors also developed a service quality assessment tool called SERVQUAL, which contains a set of 22 assessment questions associated with each service quality dimension. The set of 22 assessment questions was modified to be up-todate in 1991 [3]. Suraworachet et al. [4] conducted the study on the effect of Facebook's social network features toward intention to buy on F-commerce in Thailand. The survey results revealed that belief in

+ Corresponding author. Tel.: + 6682218 6959; fax: +668 22186955.

E-mail address:Yachai.L@chula.ac.th. 
people who like a Facebook fan page, belief in people who like a photo of an item, and belief in friends who like a Facebook page have respectively significant impact on consumers' attitude. Furthermore, attitude and perceived ease of use also have a significant effect on consumers' purchasing intention on Facebook commerce.

\section{Research Methodology}

This paper presents an approach for service quality assessment of online shops on Facebook fan page in Thailand. The quality dimensions are selected from SERVQUAL [1,2,3], including Reliability, Responsiveness, and Assurance:

- Reliability- frequency of asks for reply from the fan page; frequency of the fan page posts.

- Responsiveness- response time of the inquiry posted on the fan page.

- Assurance- number of likes; existences of shop's address, phone number, and email address.

The information of the fan page, such as likes and comments, is collected via Facebook Graph API. The Graph API is the primary means to obtain data from Facebook's platform. The concept of Graph API is based on the notion of social graph [5]. The structure of information on Facebook is composed of nodes, edges, and fields. Nodes are "thing" such as user, comment, and photo. Edges are connection between nodes. Fields are information about nodes such as description of photo, message of comment, and number of likes of a fan page. Table1 shows the information collected from the Facebook Graph API in this work.

Table 1: Collected Information from Facebook Graph API

\begin{tabular}{|l|l|l|}
\hline \multicolumn{1}{|c|}{ Node } & \multicolumn{1}{|c|}{ Node's Description } & \multicolumn{1}{c|}{ Fields } \\
\hline page & Fanpage's information & id, name, emails, phone, location \\
\hline album & Album of photo & id, message, comment, created_time \\
\hline post & Post in fanpage & id, message, comment, created_time \\
\hline photo & Photo posted by fanpage & id, message, comment, created_time \\
\hline comment & Comment in photo or post & id, message, created_time \\
\hline reply & Comment in photo or post & id, message, created_time \\
\hline
\end{tabular}

Next, the collected comments will be segmented. Examples are shown in Table 2.

Table 2: Examples of Segmented Sentences of Comments

\begin{tabular}{|l|l|}
\hline \multicolumn{1}{|c|}{ Collected Comment } & \multicolumn{1}{|c|}{ Segmented Sentence } \\
\hline ตอบ inbox ด้วยค่ะ (Please reply inbox message) & ตอบ|inbox|ด้วย|ค่ะ \\
\hline ราคาเท่าไหร่คะ (How much?) & ราคา|เท่าไหร่|คะ| \\
\hline
\end{tabular}

The keywords obtained from the previous step of segmentation of the sentences in collected comments will be then tagged as comment types, namely ask for message reply, and ask for information as shown in Table 3.

Table 3: Keywords for Tagging Type of Comments

\begin{tabular}{|c|c|c|c|}
\hline Tag of comment type & Keywords & Tag of comment type & Keywords \\
\hline \multirow{3}{*}{ ask for message reply } & $\mathrm{ib}$, inbox, ข้อความ, แชท (Facebook message) & \multirow{7}{*}{ ask for information } & ยังไง (How) \\
\hline & ตอบ (Answer) & & ขอ (Ask for) \\
\hline & เช็ค (Check) & & ต้องการ (Want) \\
\hline \multirow{4}{*}{ ask for information } & สอบถาม, ขอทราบ (Inquiry) & & สนใจ (Interested in) \\
\hline & กี่ (How many) & & ไหม, มั้ย, มั้ย (Yes/No question) \\
\hline & เท่าไร, เท่าไหร่, เท่ารัย (How much) & & ทำไม (Why) \\
\hline & เมื่อไหร่, เมื่อไร (When) & & ไหน (Which) \\
\hline
\end{tabular}

Table 4: Criteria of Service Quality Rating

\begin{tabular}{|c|c|c|c|c|c|c|}
\hline \multirow{2}{*}{ Dimension } & \multirow{2}{*}{ Subject for assessment } & \multicolumn{5}{|c|}{ Rating } \\
\hline & & 5 & 4 & 3 & 2 & 1 \\
\hline \multirow[t]{2}{*}{ Reliability } & $\begin{array}{l}\text { Percentage of ask for reply } \\
\text { comments per all comments }\end{array}$ & $0-30 \%$ & $31-40 \%$ & $41-50 \%$ & $51-60 \%$ & $60-100 \%$ \\
\hline & Percentage of daily post per month & $81-100 \%$ & $61-80 \%$ & $50-60 \%$ & $40-50 \%$ & $0-40 \%$ \\
\hline \multirow{2}{*}{ Responsiveness } & Response time for each inquiry & in minutes & within an hour & in a few hours & in a day & more than 1 day \\
\hline & Response rate & $81-100 \%$ & $61-80 \%$ & $41-60 \%$ & $21-40 \%$ & $0-20 \%$ \\
\hline \multirow[t]{2}{*}{ Assurance } & Number of Likes & $>1,280,001$ & $\begin{array}{l}960,001- \\
1,280,000\end{array}$ & $\begin{array}{l}640,001- \\
960,000\end{array}$ & $\begin{array}{l}320,001- \\
640,000\end{array}$ & $0-320,000$ \\
\hline & Number of exist information & 3 & - & 2 & - & 1 \\
\hline
\end{tabular}


Once all the information gathered from Graph API has been prepared and analyzed, the calculation of service quality rating will be performed. The five-star overall rating and the detailed rating for each subject will be provided. The overall rating will be calculated from the average of all subjects. Referring to [6], the criteria of each rating are shown in Table 4.

\section{Results}

The information of a particular fan page has been collected from October 2015 to January 2016. The selected online shop sells clothing, with the number of 1,437,074 likes (as of Feb 2016). However, this online shop does not provide any contact information, i.e. none of store location, phone number, or email address. The Facebook message is the only one contact channel provided on this fan page. This results in the 0 -star rating for the existence of information as shown in Table 7.

Precision, Recall, and F-measure, as (1), (2), and (3) respectively, are applied for the evaluation of the comment analysis. The results are summarized in Table 5.

$$
\begin{aligned}
& \text { Precision }=\frac{\text { correct comments found }}{\text { total hLmber of comment founc }} \\
& \text { Recall }=\frac{\text { corvectcommens found }}{\text { toinl hLmber of related commentr }} \\
& \text { F-measure }=\frac{\eta \times \text { Precision } \times \text { Recall }}{\text { Precision }+ \text { Recall }}
\end{aligned}
$$

Table 5: Evaluation Results of Comment Analysis.

Table 6 shows that this fan page has about 5,000-10,000 comments per month. It is observed that the requests for reply posted by customers are mostly found in the fan page's timeline, while the requests for product information are mostly found in the comment posts and photos in timeline. This fan page thus seems not likely to reply the customer's inquiry compared to the number of comments, resulting in low rating of comment response time and comment response rate in Table 7.

Fig. 1 shows the frequency of the daily fan page's post. This fan page posts every day, therefore, it is rated 5-star for frequentness of post as shown in Table 7.

The overall rating of this fan page is 2.80 (moderate) as shown in Table 7. This fan page is outstanding (5-star) on customer message reply, and frequent posts. It is rated good (4-star) for customers' likes. However, the rating of comment response and information is very low. The fan page is suggested to provide the customers for the contact information, so that it could be higher rated.

Table 6: Analysis Results of Posts and Comments
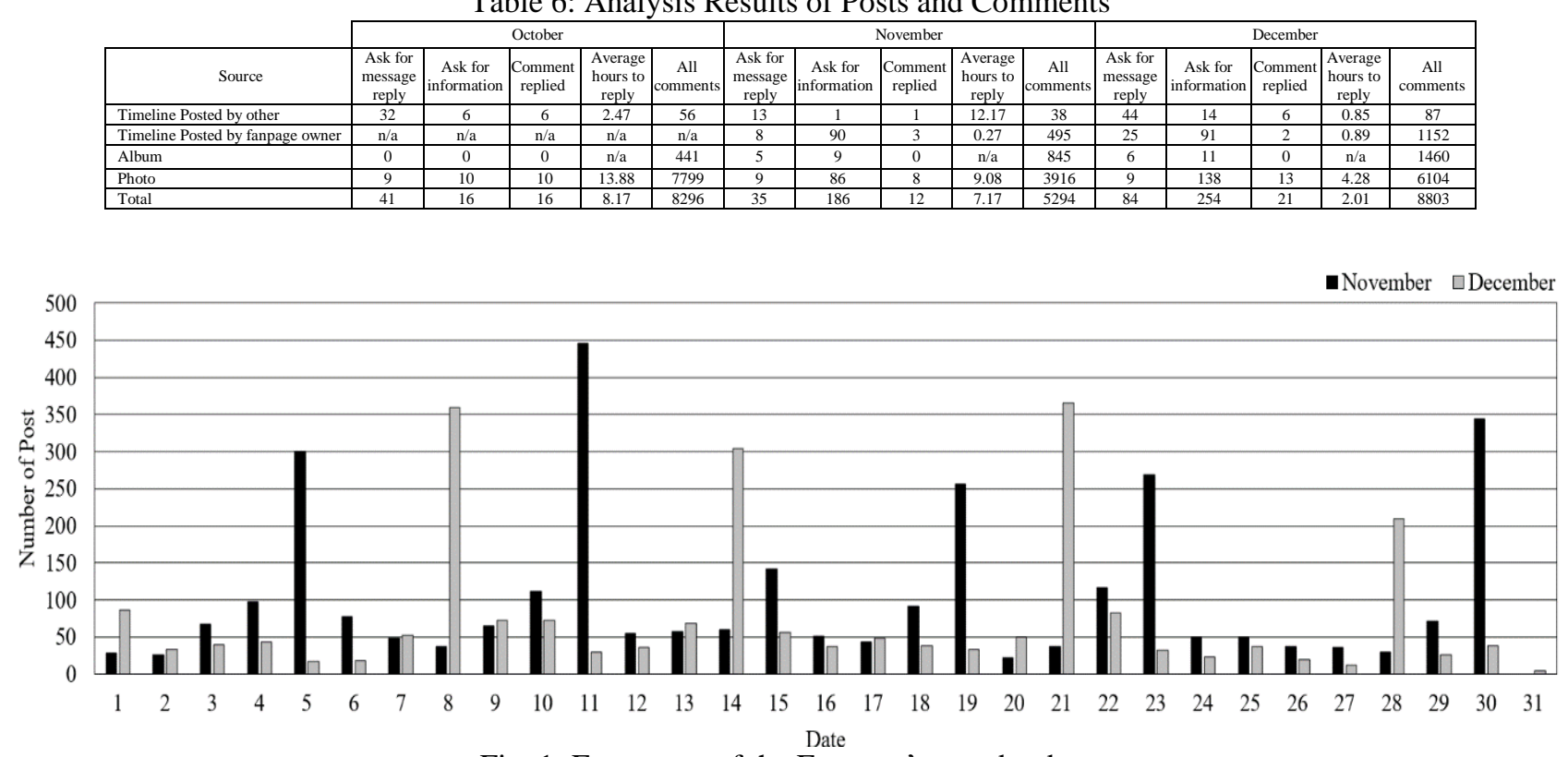

Fig. 1: Frequency of the Fanpage's post by date. 
Table 7: Service Quality Assessment of Selected Online Shop on Fan Page

\begin{tabular}{|c|c|c|}
\hline Subject & \multicolumn{2}{|c|}{ Rating } \\
\hline Overall & 2.80 & 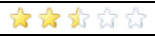 \\
\hline None of customer ask for message reply & 5.00 & 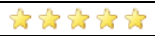 \\
\hline Frequentness of post & 5.00 & 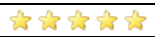 \\
\hline Comment response time & 2.00 & 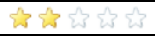 \\
\hline Comment response rate & 1.00 & 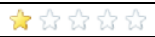 \\
\hline Likes & 4.00 & 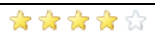 \\
\hline Existence of inform & 0.00 & \\
\hline
\end{tabular}

\section{Conclusion and Future Work}

This paper presents an approach for assessing service quality of Facebook fan page shop from information, posts, and comments. The SERVQUAL model $[1,2,3]$ is applied for the development of quality dimensions and the subjects of assessment in this work. The implementation of the proposed method would help the customers make decisions for their online shopping. The enhancement of the presented method would be the additional sources of information gathering, i.e. the keywords could be collected from other categories of fan page like toy, stationary, mobile phone accessories.

\section{References}

[1] A. Parasuraman, V.A. Zeithaml, L.L. Berry. A conceptual model of services quality and its implication for future research. Journal of Marketing. 1985, pp. 41-50.

[2] A. Parasuraman, V.A. Zeithaml, L.L. Berry. SERVQUAL: A multiple-item scale for measuring consumer perceptions of service quality. Journal of Retailing. 1988, pp. 12-40.

[3] A. Parasuraman, V.A. Zeithaml, L.L. Berry. Refinement and Reassessment of the SERVQUAL Scale. Journal of Retailing. 1991. pp. 420-450.

[4] W. Suraworachet, S. Premsiri, N. Cooharojananone. The study on the effect of Facebook's social network features toward intention to buy on F-commerce in Thailand. Int. Symp. On Application and the internet. 2012. pp. $245-250$.

[5] Facebook, https://developers.facebook.com/docs/graph-api/overview

[6] Zocial M Co.,Ltd., http://zocialrank.com/facebook/index.php?cc=TH\&cat=34\&page=1 